\title{
Growing Up French? Education, Upward Mobility, and Connections across Generations
}

\begin{abstract}
Many people of color living in this country can likely relate to the onset of outsized ambition at too young an age, an ambition fueled by the sense, often confirmed by ignorance, of being a second-class citizen and needing to claw your way toward equal consideration and some semblance of respect. Many people of color, like me, remember the moment that first began to shape their ambition and what that moment felt like.

—ROXANE GAY, “THE PRICE OF BLACK AMBITION”
\end{abstract}

France views and portrays itself as a white country. My whole life, I've felt erased by the national narrative. People even keep complimenting me on how good my French is. It's deeply embedded in the national consciousness that "true" identity is one that has been here forever.

- ROKHAYA DIALLO, FRENCH JOURNALIST AND WRITER OF SENEGALESE ORIGIN

On a February morning sitting in a café near the Palais Garnier at place d'Opéra, Safia-a petite and professionally dressed thirty-two-year-old with dual Tunisian and French citizenship-described her experiences growing up in France with Tunisian immigrant parents. Safia remembered the shame and humiliation her parents experienced because of their immigrant status, lack of educational attainment, and illiteracy:

I remember working very hard in school because I really wanted to escape my social background. I didn't want to be as poor as my parents or mistreated. Because when you don't know French perfectly well or have a certain level of education-especially when you're an immigrant-that's what happens. So I said to myself that when I grow up, it's out of the question to be treated like that. And I also worked hard because I 
wanted to earn a lot of money, to help my parents, to have my parents be proud of me, so it was a bit of a social retaliation there.

Safia grew up in a middle-class neighborhood near the Musée du Louvre with her two younger brothers and younger sister, who all still live in the Parisian metropolitan area. Her parents migrated separately to France, where they then met and got married. ${ }^{1}$ Her mother had been widowed in Tunisia and immigrated to France to "make a change in her life." Her father came to France for better employment opportunities. Despite speaking little French and communicating mostly in Arabic, they were able to make do-get around, read metro signs, and make a life in Paris. Her father worked as a cook and her mother worked as a nursery school assistant.

Growing up, Safia always had cousins and other extended relatives living with her family, particularly in the initial months after these relatives immigrated to France. In retrospect, Safia thinks it was great having these other relatives around because it helped her learn about various aspects of maghrébin culture.

Safia remembers learning she was different when she entered high school and a classmate told her she had "matte" skin. From that moment on, she understood that she would "never be completely considered as a French person." This only intensified as she grew older. As a law student, she remembers classmates calling her a dirty Arab and telling her she should return to her country. Safia remembers constantly being reminded of how she did not belong, particularly in an environment of mostly white students and faculty. "I remember crying a lot during that time," she explained.

However, she managed to be successful in her studies, earning both undergraduate and graduate degrees. Safia now works as a journalist and rents an apartment in Cergy-Pontoise, a western banlieue, with her two young children and her husband, who is a child of Algerian immigrants and works as a banker. There is much that makes her proud to be French, such as the values exemplified in the motto of " $\mathrm{Lib}$ erté, égalité, fraternité." But she hates that her "Frenchness" is still often questioned by others: "Today, when I'm with my children, people still ask me, 'What are your children's origins?' or 'Where do you come from?' That drives me crazy, because my children were born in France to French parents. And me, I was born here, my children were born here, and they still ask me that. It is so annoying to have to continually justify myself based on the color of my skin or the color of my children's skin.”

Safia feels her place in France is questioned because she of her maghrébin origin. Reflecting on her status in French society, she feels that she is "French in the second degree." Despite her middle-class status and educational and professional accomplishments, she nonetheless feels like she occupies a France that continually reminds her of how her visible difference and nonwhite status excludes her from being accepted as French by others.

Like Safia, most respondents remember when they first felt different-because of their maghrébin origins - from others growing up. Yet intergenerational mobility is complex for immigrant-origin individuals. Despite her upward mobility 
vis-à-vis her immigrant parents, she is not treated much different from them on an everyday basis. While Safia is very accomplished in realms of education and employment, she remains marginalized. Throughout Safia's childhood, she worked hard to counter the stigmatization her parents faced, yet because she could not change the thing that really mattered-being nonwhite-she did not dramatically change her status in relation to mainstream society. She continues to be denied cultural citizenship by her fellow French citizens.

In this chapter, I discuss respondents' childhood experiences and how these experiences shaped both their upward mobility up to and including adulthood and sense of social marginalization in wider society. Respondents learn that they are not seen as French by others as children. And they are continually reminded of this difference as adults. While all my respondents grew up in France, they did not grow up feeling French, for they were told at a young age that they were different or treated and seen as outsiders. I therefore situate growing up French as a question because many respondents remember how their "Frenchness" was questioned starting at an early age: Do they really grow up French?

Moreover, children of maghrébin immigrants had to navigate two different seemingly incompatible cultural worlds-home versus school, or maghrébin versus French. I investigate the messages these individuals received from their parents and extended family regarding what it means to be French, as well as how these compare and contrast with the messages they received at school, both in their primary and university educations. Because of this distinction, children of North African immigrants had to become "cultural brokers" (Sharma 2010), bridging different cultural worlds. I also trace the influence of these messages on their later upward mobility and unpack the cultural repertoires and cultural and social capital this generation inherited from their parents. Respondents' childhood experiences set the stage for their later upward mobility and attainment of middle-class status. For children of immigrants who are also racial and ethnic minorities, the processes of identity formation are especially complicated, as these individuals must situate dual cultural worlds within a particular racial and ethnic hierarchy (Ali 2008; Waters 1999). Their experiences might be different if they were second-generation Italian or English immigrants and did not have to navigate their second-generation status while also being an ethnic minority connected to a colonial history. In France immigrant-origin individuals also must navigate this in the absence of state-sanctioned identity categories.

\section{LEARNING OF ONE'S DIFFERENCE: \\ HOME VERSUS SCHOOL}

As Zara describes the boundaries in her Perpignan community: "There were Français du souche and there was everyone else." Born to an Algerian immigrant mother and a Moroccan immigrant father, Zara, a twenty-eight-year-old, 
remembers learning she was different in her predominately white elementary school when her schoolteacher did not understand what the henna on her hands meant and made her wash it off her hands. This experience was her first denial of cultural citizenship. Growing up in Perpignan, in southern France, she had many experiences like this one, which helped her realize she was étranger, or foreign. She also remembers getting dirty looks and stares from other students when she did not eat pork at the school cafeteria because it was not halal.

It was early childhood moments like these that reinforced dual cultural worlds to Zara. Her way of life at home was markedly different from her life at school, and this difference was something that not everyone had to consider. In France there was and is a stigma attached to North African origins, and children of North African immigrants grow up with messages from society at large that they should be ashamed of such origins. They became conscious of the distinction between the maghrébin and French cultural worlds, and its consequences, through their parents' socialization of them.

Zara's family, including her two older brothers and one younger brother, was one of only five maghrébin-origin families in her neighborhood. Her father worked as an electrician and her mother was as a homemaker. Both parents stopped attending school just before high school. Twenty-eight years old and living in SeineSaint-Denis, Zara works as a social worker in the nineteenth arrondissement and is actively involved in cultural, social, and political organizations related to maghrébin life in France. Her early experiences continue to resonate in her work with maghrébin-origin youth.

School is where children of maghrébin immigrants learn both Republican principles and what it means to be French, which in turn shapes how they define themselves in French society. These factors also shape the boundaries respondents draw around French as an identity, and the degree to which they claim such an identity as adults. Education is an important means of Republican integration, and school is often the first state institution that immigrant-origin individuals confront (Fernando 2014; Rojas-García 2013). It is where they are exposed to French history and the boundaries of French national identity. As Pierre Bourdieu (1984) articulated, the French educational system values the culture of the dominant class and enacts a "symbolic violence" against other individuals by delegitimizing their values and concealing the power relations inherent in doing so. This symbolic violence becomes meaningful as symbolic distinctions are translated into real social boundaries.

School is also a site where difference is learned and reinforced (Kleinman 2016). Through the homogenizing nature of its curriculum, school also reifies a national history and national cultural repertoire, one that often excludes the contributions of immigrant-origin individuals (Keaton 2006; Lamont 1992). ${ }^{2}$ This automatically marginalizes children of immigrants and contributes to how symbolic boundaries 
are translated into social boundaries around French identity and citizenship. It is, therefore, no accident that controversies over wearing the hijab, or Islamic headscarf, are often situated in schools because it is framed as contrary to French national identity and French schools are Republican institutions (Fernando 2014; Judge 2004; Raveaud 2008).

Because education is relatively centralized in France, schools are crucial sites for producing French citizens and instilling Republican principles (Bowen 2008; Chabal 2015; Keaton 2006; Maier 2004). ${ }^{3}$ As their parents were not educated in the French Republican system, children of North African immigrants often receive the most significant messages about what it means to be French from their school. Schools are also sites of otherness for this population, since it is where children of North African immigrants first feel inferior to and different from their white classmates (Noiriel 1996). Their early educational experiences therefore influence how they understand their social location. Martinique-born philsopher and writer Frantz Fanon (1967) discuses how in his homeland (an overseas département-a major administrative subdivision or branch of government in France) schoolchildren were told to look down on their native creole language in favor of French, which helped create a separation between the worlds of home and school. Similarly, in Spain schoolteachers exclude immigrant children from Spanish cultural citizenship, which in turn shapes immigrant-origin children's notions of national belonging (García-Sánchez 2013). This is not unlike how the American educational system reifies a particular American ethos and historical narrative, which marginalizes those individuals seen as outside this dominant narrative.

The North African second generation experienced a dual education-one in French schools and another at home. School thus serves two identity-related functions for this population-it defines what it means to be French and distances them from this definition. Members of this group must then work through how to reconcile these two educations, which have different implications for their identities. School mainstreams individuals by socializing them in the norms and values of mainstream society (Carter 2005; Maier 2004). Yet there is a limit to the degree to which school mainstreams the North African second generation. They are socialized in these norms and principles of mainstream society but kept apart from it. School helps establish cultural citizenship and then reinforces its denial.

Sabri's experience is an example of this phenomenon. Growing up with four siblings in one of the only immigrant-origin families in Amiens, a town in northern France, he was reminded of his difference at an early age:

I realized when I was around eight or nine or ten years old, that we were different from other people; the other children recognized that, meaning that they'd tell us, "You're Arab; go back where you came from; you're not from here," and other insults. There were not many immigrants, maybe three or four families. . . . Everyone else was white. We quickly understood the image that they had of us. For that reason, we 
understood we were different from others. ... We felt different and not completely

French, and that remains today.

Sabri would tell his parents about incidents in which he was insulted. However, although they were upset, they could not do anything because they experienced the same discrimination. These experiences were clearly traumatizing for Sabri. Though thirty years old and an eight-year resident of the Parisian metropolitan region (he lives in Porte de Saint-Ouen, a banlieue north of Paris) when we met, he is still reminded that his maghrébin origin marks him as different-in a society that supposedly does not mark racial and ethnic differences.

The experiences of the North African second generation bring to mind Fanon's realization that, as a nonwhite, he was therefore different. In Black Skin, White Masks, he recalls how, when in France a white boy identified him as black to his mother: "For the first time, I knew who I was. For the first time, I felt as if I had been simultaneously exploded in the gaze, in the violent gaze of the other, and at the same time recomposed as another." Like Fanon, who was labeled black, Sabri was labeled other, something outside the norm, nonwhite, not French. They are "forever foreigners" (Lowe 1996) within France, the country of their birth. Yet despite their later successes, particularly compared to their immigrant parents, the North African second generation is unable to escape this assigned otherness. This is a difference that is imposed on them at a young age, not one they themselves choose.

\section{CULTURAL CAPITAL AND CONNECTIONS ACROSS GENERATIONS}

I will now discuss the influence of their immigrant parents on respondents, including the messages they received about being maghrébin and French and how this shaped their later experiences, and how they understand those experiences. Although respondents received somewhat differing messages from their immigrant parents, they all experienced marginalization by their white counterparts. As school provided one message regarding what it means to be French and how immigrant-origin individuals are outside this definition, home provided a contrary narrative helping to situate them as racial and ethnic minorities within France. Often, respondents discussed how their parents (and other relatives) provided them cultural tools and frameworks to make sense of their social locations. Cultural capital, meaning "skills individuals inherit that can be translated into different forms of value as people move through different institutions" (Lareau $2015,4)$, is transmitted through one's family. For children of North African immigrants, this cultural knowledge involves navigating being maghrébin in France and preparing them for the obstacles they will face, which become particularly acute as they move through spaces where there are few other racial and ethnic 
minorities. Such cultural capital allows them to make sense of their maghrébin backgrounds, which are continually and simultaneously marked and denied in France-denied in the sense of being viewed as part of French culture and history and marked in the sense that maghrébin-origin individuals are never seen as French.

For example, Safia learned both directly and indirectly from her parents the difficulties of being an immigrant in France. This fueled her in part to improve her social status, through work and educational attainment. Sabri feels that he learned what it means to be a Tunisian from his parents; it's "what they gave [him].” But beyond teaching him about being Tunisian, they related how to be a Tunisian-origin individual in France and reinforced the connection between his life in France and his parents' and extended family's lives in Tunisia. He learned how his life in France is an extension of his family's life in Tunisia. "That is where the clash comes in, meaning the meeting of the two, how to find an equilibrium between Western society and maghrébin culture, how to synthesize it all. Some people can do it, some cannot. As for me, I do not say that I've figured it out; I am always trying to find a compromise, it is a continual negotiation," he explained. Developing his own identity as he has grown up has involved reconciling his Tunisian origins with his existence as a French person.

One mechanism for transmitting cultural capital from the first generation to the second was trips to the Maghreb, often to visit relatives during the summer. For example, Diana, a twenty-four-year-old of Algerian origin, has traveled to Algeria at least once a year since she was a child. She often spent the summers with her seven older siblings in a small village, which she describes as very traditional, where most of her extended family lives.

When I return there, I have the impression of being closer and closer to my origins, to the rest of my family. . . . My grandparents are buried there, and I just find that so important, to not forget where I came from, where my parents came from, to really see their path, to where they are today. They have really lived through some things, they were born in these small villages, and they ended up, for my father, destined to be farmers taking care of the land, my mother taking care of her children. ... They evolved with the times, transmitting all their culture, all their values, which were developed in a context that is totally different, that had nothing to do with France.

When I press Diana on what exactly she feels she learned from her parents, she explains:

Well, the language for one-that's very important in terms of culture. Also, the food. I know that sounds silly, but as an adult, I know how to make all the dishes I ate as a child, the ones that are really typical from the region where my parents grew up, that people of the same origins as me eat. I learned how to make these dishes from my parents, and I really liked that. ... As for the story of what drove us from Algeria, my parents have told me about that time. It was difficult for them to talk about at first, 
because they lived through the Algerian War of Independence, and that was really difficult for them. It's true that they have lots of awful memories, of losing members of their families, their parents, et cetera, who were part of the Algerian resistance.... And it was a really difficult period-they didn't have easy access to food. Really, their story is the story of Algeria. We don't feel it much anymore. But since I was born-I really wasn't that old-I have understood better the change or the shift, the history even. Because it's true that we read books and learned it a little, but living it through people who lived it is important to have a sense of this war, and what stemmed from it, so even at a cultural level I find that it's very important to transmit a culture, the culture of your country to your children.

Diana conveys how her existence in France stems from its colonial relationship with Algeria. This is a history that is both intertwined with and separate from her everyday life in France. Her Algerian origins have direct implications for her social status in France, including the otherness assigned to her. Her parents recreated their culture within France, namely, through the Arabic language and a particular cuisine. But part of their connection to their Algerian culture requires acknowledging that colonial relationship and its psychological and material consequences for Algerian immigrants and their descendants. Diana recognizes the intense struggle of her parents, even while she faces the difficulties of being a maghrébinorigin individual in France. As an adult, she can feel connected to Algeria, at least in part through her regular travel there, while also recognizing how different her life would have been if her parents had not immigrated to France. Because of her own experiences growing up as well as her knowledge of her parents' history, Diana dislikes how immigrants and their descendants are referenced in France. ${ }^{4}$ She feels that most immigrants are very respectful of French law, and that their descendants are just as French as anyone else. They do not have to integrate, since the French culture is the one into which they were born and in which they grew up. It is their culture, too.

Other respondents also referenced childhood travel to the Maghreb as helping situate their lives in France and fulfilling an important cultural function. Hicham, a twenty-nine-year-old of Moroccan origin, visited Morocco every summer during his childhood with his parents and four younger brothers. Now, as an adult, he goes whenever he can. He says, "It allows me to rediscover my origins, language, customs, family. It's just not the same unless you go there." He anticipates doing the same thing for his children. Semi, a thirty-six-year-old of Tunisian origin who lives in the twentieth arrondissement, spent much of his childhood, sometimes entire years, living in Tunisia. His parents wanted him to have that experience so that he "could discover his origins, history", he explained. "Many secondgeneration immigrants in France are not in a good situation; many of them do not know where they are from." Semi thinks it has been easier for him to live in France because of his experiences in Tunisia. He has a better sense of his culture 
and origins than other children of North African immigrants and feels he is more grounded then they are.

Similarly, Soria, a thirty-four-year-old of Algerian origin who lives in a condo in the fifteenth arrondissement and has worked as a human resources director for the past decade, grew to appreciate her Algerian origins because of, in no small part, an extended trip she took to Algeria when she was a teenager: "One of the best moments of my life, the most life changing, was when I spent four months in Algeria. It allowed me to gain what I had been missing, notably in relationship to my identity. When I returned, I started speaking Arabic more, because before, when I spoke to my parents, I spoke in French, and now ever since then I've always spoken Arabic with my parents."

Her travel to Algeria allowed her to capture something previously unavailable to her had she never visited. However, her Algerian connection is not without its complications. Soria does not travel there as often now because she is not as close to her family there, and also because security concerns make her increasingly anxious about possible terrorist attacks in Algeria. Her attachment to Algeria has become less about the place and the need to physically be there and more about how Algeria represents a connection to her immigrant parents, to French colonial history, and to Algerian culture. The Arabic language plays a role in strengthening connections across generations in maghrébin-origin households. It is not uncommon for children of North African immigrants to return to studying (or speaking) Arabic later in their lives, as it remains the "highest-status vehicle for religious knowledge," though the language itself is gradually declining in maghrébin-origin Muslim households (Bowen 2004b, 48; see also Cesari 2002).

Samir, a twenty-nine-year-old of Algerian origin pursuing a doctorate in political science, remembers growing up in Tours and feeling uncomfortable owing to his visibility as a member of one of the only Algerian families in his town. He felt his teachers did not understand him and thought he was different and strange. Samir also vividly remembers tensions with white neighbors. He valued his frequent travels to Algeria to see his family and believes they counteracted his experiences growing up in Tours. He explained to me how Algeria is the site of his "culture of remembrance," as opposed to his present culture, which is in France.

As these representative examples suggest, the connection between the middleclass North African second generation and parents of maghrébin origin, developed through, for example, summer vacations and stories related to them by relatives, is a tool that helps them make sense of the marginalization they face in France. For many respondents, travel to their parents' maghrébin country of origin further reinforced their difference and illuminated their denial of cultural citizenship within France. 
Beyond travel to the Maghreb, children of North African immigrants recalled specific messages their parents gave them about growing up in two different cultural worlds. Mohamed, a thirty-year-old of Algerian origin, remembers how his parents reinforced that home was France. He grew up in Avignon, near Marseille, in the south of France, with his four brothers and two sisters. His father was a factory worker and his mother a domestic worker. His father had originally come to France to work for a few years and then returned to Algeria. However, he found he was uncomfortable there. He returned to France in the mid-196os with his wife and had seven children there, Mohamed being the youngest. What he learned from his parents was contrary to what he learned at school: he was taught at an early age that he was different from whites. Growing up, the mixed messages were challenging for Mohamed. As an adult, he sees his French and maghrébin status as a richness. He locates himself in the liminal space between what his parents taught him about being of maghrébin origin in France and what he learned at school; that is, he is simultaneously maghrébin and French.

These connections between the first and second generation are both symbolic and real. Cultural capital allows individuals to be able to navigate a diverse number of situations. What children of North African immigrants learned, both explicitly and implicitly, from their parents reflects the complications inherent in being both descendants of immigrants as well as racial and ethnic minorities. Their schooling imparted certain messages to these children, and their parents helped them interpret and confront them through their own cultural capital. Despite their education in a French Republican school, respondents quickly learned that they were not a part of the French Republic. Though they tried, their parents were ill-equipped to help them navigate this dual status. As first-generation immigrants, they themselves were never assumed to be part of the French mainstream. And yet neither are their children.

\section{HIGHER EDUCATION}

That children of immigrants felt different from others was also reinforced by their university education. All respondents have a university education above the baccalaureate level. ${ }^{5}$ Higher education facilitates their upward mobility into a middleclass status yet erects barriers to their full societal inclusion.

I noted earlier how Abdelkrim's sense of having been marked as different was heightened when he began his university studies in Tours. "We [he and the other students] don't have the same lives," he explained. "The more you advance in your education, the harder it is to find people like you." The quest for compatibility is not limited to maghrébin-origin individuals in France but also applies to racial and ethnic minorities around the world, whether they are African Americans in predominately white colleges and universities or immigrant-origin individuals in 
a predominately white town or neighborhood in some other corner of the globe. French higher education does not systematically address its lack of ethnoracial diversity. ${ }^{6}$ This can create added complications for individuals like Abdelkrim, who may have had similar and like-minded friends growing up but have difficulty making connections in a university setting. This has implications for the development of one's identity and the perception of one's status in society at large, as research on racial and ethnic diversity in higher education and the workplace attests (Feagin 1991; Tatum 1997).

By most accounts, Mourad, a thirty-year-old of Algerian origin, is very successful. He will soon earn his doctorate from the Institut d'études politiques de Paris, better known as Sciences Po, and also works as a freelance writer. He lives in an apartment in the seventh arrondissement, a neighborhood near the Eiffel Tower, which he described to me as "very rich and very white." Mourad is very close to his parents. His father immigrated to France in the 1960 os for factory work; his mother migrated about ten years later, caring for Mourad and his five brothers and one sister. His parents are not educated, which he explains was common in Algeria at the time of the Algerian War of Independence. Mourad remembers being marked as different at a young age, including being called an Arab as well as ethnic slurs by his classmates. Yet he managed to complete his studies in political science and sociology and earn a master's degree studying immigration in the Arab world. He is the recipient of a prestigious fellowship funding his doctoral research on the French military.

Still, Mourad acknowledges how hard it has been to accomplish all of this and cites the various barriers he has faced along the way because he is not white. He explains that coming from a modest and maghrébin-origin background, it is not easy to succeed:

It's difficult, difficult, because, for example, to complete your studies you are obliged to have a side job. ... I'm a student at Sciences Po. It's a prestigious university in France. Because my parents cannot afford to give me money, I must have a side job. That means that I have less time to complete my studies, so that adds a lot of pressure. . . . It's difficult to come from a modest background, whether you're of immigrant origin or not, because in France there are a lot of barriers. . . I think that in French society, to climb it, you need to go through the grandes écoles [prestigious, university-level colleges that require entrance examinations], and in France these schools remain very, very white and bourgeois. Actually, the university is democratized in France; there are many minorities in the regular universities, Paris 8, Paris 1 , and Paris $2 .^{7}$ But ... it's not because you have a diploma from a university like this in France that you are going to experience social mobility, because what's happened is that a lot of people have these kinds of degrees, and so the value of that diploma is lowered. That means that if there are five hundred people who have a master's, there are not a lot of jobs that require a master's, so there are a lot of people who are going to be left out. Myself, I know people who have a bachelor's, who have a master's, who 
have jobs that don't have anything to do with [their degrees or topic of studies], who work at McDonald's, places like that. So there are people from modest backgrounds who are at universities, it's true. However, the grandes écoles, they remain as before. With the exception of Sciences Po, which has been making small steps in the past four to five years, the other grandes écoles-Polytechnique, Ponts et chaussées, ESSEC, HEC-remain [mostly white and bourgeois].$^{8}$... In France, if you really want to move up, to advance socially, it's necessary to go through the grandes écoles.

Mourad recognizes the education necessary for upward mobility. Approximately one-fourth of respondents attended or attend these schools. ${ }^{9}$

When he finishes his doctorate, he hopes to become a university professor, though he realizes how many more obstacles exist at that stage. Mourad has confronted the same obstacles throughout his educational trajectory. He frames his experiences of higher education in France simultaneously as linked to his ethnic origin and working-class background. He is not just working-class and upwardly mobile, but also maghrébin. A focus on just socioeconomic status or class would omit the salience of race and ethnicity for determining his life path.

Despite his successes, Mourad fully realizes the barriers that all maghrébinorigin individuals face-regardless of socioeconomic status. He recounted to me how he and his other North African-origin friends are regularly stopped by the police, who check their identification (the French version of stop and frisk). ${ }^{10} \mathrm{He}$ has also been followed in department stores by salespeople and been denied entry to nightclubs regardless of how he is dressed.

While higher education is a means to upward social mobility, it is not without its complications. Members of the maghrébin second generation are also firstgeneration university students. Their higher education again reminds respondents of their difference from the mainstream. And it also reveals how the denial of cultural citizenship continues for these individuals well into adulthood.

\section{NAVIGATING TWO WORLDS: BETWIXT AND BETWEEN}

The 2004 French film Le grand voyage (The Great Journey) by director Ismaël Ferroukhi, who was born in Morocco before moving to France as a young child, beautifully illustrates the complicated connections between maghrébin immigrants and their children. Réda, the teenage son of Moroccan immigrants, accompanies his father on a pilgrimage to Mecca from southern France. His father insists on communicating in Arabic, while the son speaks French. Their tense interactions across eight different countries reveal how children of maghrébin immigrants live in dual worlds-in their parents' traditional culture and the Westernized French culture in which they have grown up. 
In France the denial of cultural citizenship through an assigned otherness begins in childhood and is reiterated throughout primary, secondary, and higher education. Children of North African immigrants must navigate two cultural worlds-French and maghrébin. This reflects the cultural citizenship they have been denied, which positions their maghrébin origins as non-French. Those cultural worlds were often in conflict or positioned against each other. This dynamic is true for other minority populations in different contexts as well, including Latino and African American students in the United States who must straddle multiple cultural worlds or invoke multiple cultural repertoires-the dominant culture versus the culture of their minority group (Carter 2005). However, the maghrébin second generation does this in a context where, ideologically speaking, they should not have to. Per French Republican ideology, they are as culturally French as any other French person, so long as they adhere to the values of the Republic. In this context, navigating two cultural worlds-and never being firmly in one or the other-reveals the degree of their marginalization, or distance from mainstream society. They move and interact in the dominant cultural world but remain outside of it. In this context, the North African second generation is never allowed to see itself as whole or integrated; rather, French culture and North African culture are placed in opposition to each other.

Moreover, their attachment to dual cultural worlds or, as Samir puts it, their "belonging to two universes", is something their white peers do not face. However, Mohamed grew to see this as beneficial. "Growing up, I didn't really understand it," he explained. "But now I see it as more of a positive thing. . . . It has added to the richness of my life." Mohamed's ability to reframe his narrative has helped him be successful as a technical director for his company. Because he is middle-class, he can access multiple codes to navigate different kinds of spaces. His and his peers' middle-class status forces them into the role of cultural broker (Warikoo 2011), as they must bridge the differences between French and maghrébin cultures, as well as the differences between the cultural worlds of the middle-class and the working class.

I opened this chapter by situating growing up French as a question, and I want to return to it now. As my respondents' experiences reveal, they grew up in France, but they did not necessarily grow up French. That matters, because it reveals the limitations of the Republican model for incorporating or including nonwhite individuals. It also underlines how France, historically, has not acknowledged race and ethnicity as salient. The North African second generation learned about their difference from mainstream society at an early age. Their Frenchness, or their place within the Republic, has been questioned by others since they were young. The denial of their cultural citizenship involves the continual questioning and denial of their belonging in France. And this begins in childhood, when they learn of their visibility as racial and ethnic minorities. Most individuals did not 
grow up believing that they were legitimate members of the Republic. Essentially, they were socialized into what they are not-that is, not French. They continue to navigate this dual status and opposition between French and maghrébin in other spheres, including Islam, the workplace, place, and the public sphere, as part of being middle-class. 